\title{
Introduction to the article by Harold Biswell: Prescribed Burning in Georgia and California Compared
}

\author{
Scott L. Stephens ${ }^{1 *} \mathbb{D}$, Jan W. van Wagtendonk ${ }^{2}$, James K. Agee ${ }^{3}$ and Ronald H. Wakimoto ${ }^{4}$
}

\begin{abstract}
Harold Biswell first learned about the benefits of prescribed fire in forest management when he was a Forest Service researcher in Georgia, USA. After he accepted a professorship in the School of Forestry at the University of California, Berkeley, USA, he was surprised to find out that prescribed fire was not an accepted practice in California. He set out to conduct a series of studies to explore the effects of prescribed fire in forests of California and compare those effects to those he observed in Georgia.
\end{abstract}

Keywords: Berkeley, California, Georgia, prescribed burning, University of California

\section{Resumen}

Harold Biswell primero aprendió sobre los beneficios de las quemas prescriptas en el manejo forestal cuando era investigador del Servicio Forestal de los Estados Unidos (USDA) en Georgia, EEUU. Luego de aceptar ser profesor en la Facultad de Ciencias Forestales de la Universidad de California en Berkeley, EEUU, se sorprendió al descubrir que las quemas prescriptas no constituían una práctica aceptada en California. Se las ingenió para conducir una serie de estudios para explorar los efectos de las quemas prescriptas en bosques de California y comparar esos efectos con aquellos que él mismo observó en Georgia.

\section{Introduction}

Professor Harold Biswell published an article in the Journal of Range Management in 1958 in which he compared prescribed burning in California and Georgia, USA, pine (Pinus L.) forests titled "Prescribed Burning in Georgia and California Compared" (Biswell 1958). The first question that has to be asked is why was this article published in a range management journal when the focus was on forests?

Biswell was hired as a range management faculty member in the School of Forestry at University of California, Berkeley (UC Berkeley), USA, so he had more

\footnotetext{
* Correspondence: sstephens@berkeley.edu

'Department of Environmental Science, Policy, and Management, 130

Mulford Hall, University of California, Berkeley, California 94720, USA

Full list of author information is available at the end of the article
}

connections to the Journal of Range Management. Additionally, most forestry faculty members in his department did not support prescribed fire research in forests, which probably led him to pick this outlet. Biswell was very interested in prescribed burning and thought his research could lead to better decisions for managing pine forests.

Biswell conducted prescribed fire research in the forests of Georgia from 1942 to 1947 when he was a researcher for the US Forest Service Southern Research Station. Before doing this work, he had very little experience with fire and even wrote, "At the time the idea of burning was fairly new to me and I looked upon fire as the arch enemy of forests and forestry." Biswell was a keen observer and had an open mind and found that 
using fire in the management of Georgia's pine forests was a sound practice based on ecological principles.

Biswell began his prescribed fire work in California ponderosa pine (Pinus ponderosa Douglas ex Lawson \& C. Lawson) forests in 1951 and the article in the Journal of Range Management reports on what he had learned. Two sites were used: Teaford Forest near the town of North Fork in the southern Sierra Nevada, and the Hoberg's Resort north of Middletown in the North Coast Range. Because no state or federal forest manager would allow Biswell to burn, he developed relationships with the two private landowners.

Biswell noted that only one other paper had been published on the use of prescribed fire in California forests (Bruce 1923) and it found that fire was not useful for numerous reasons. However, Biswell noted that great changes had taken place since the paper was published and some of the reasons advanced for not burning, such as damage to residual trees and the potential for fire escape, were no longer valid, especially in the light of the information gained from his research. Biswell had seen prescribed fire used successfully in Georgia and thought it could also be used in California. He said this was important because, "...frequent light fires had probably been the most important force molding the virgin forests of California."

Biswell presented information regarding the different fuels that carried prescribed fire in the pine forests of Georgia and California. In Georgia, the fuels were grasses that dried quickly and could burn satisfactorily within one to two days after rain, with four to five days after rain producing conditions too dry to burn safely in heavy accumulations of live and dead fuels. In California, the fuel that carried his prescribed fires was ponderosa pine litter. He burned mainly in winter after a few dry days when larger fuels and duff would be too wet to burn, but pine litter would be dry enough to carry a fire. He believed that a burning interval of five to ten years would be satisfactory to maintain ponderosa pine forests at low levels of fuel hazards.

Biswell investigated the number of annual burn days in Georgia and California. In Georgia, weather records that could be used to define burn days were not kept, but he estimated that there were never more than 20 to 25 days per winter when all favorable conditions combined for safe and effective burning. In California, records were kept for four years at Hoberg's, which showed that the number of burn days varied from 47 to 74 per season. January and February were particularly good months for burning, with 29 and 30 successive burn days in winter 1952-1953 and winter 1955-1956, respectively.

Biswell stated that his recommendations to use prescribed fire to manage pine forests were based on several years of actual experience. He noted that prescribed fire was a common practice in the forests of the southeastern US but scarcely tested in California before 1951. Biswell noted that wildfires were getting more destructive in California and wrote that 57110 ha (141122 acres) of timbered land burned in an 18-day period in 1955 (today, many individual wildfires are much larger than this cumulative area). Biswell's research investigated several aspects of prescribed fires in ponderosa pine forests, including effects on soil fertility and nitrogen, duff removal and accumulation, runoff and erosion, forage and plant succession, fuel reduction and accumulation, forest wildlife, and costs (see his references for more information). He stated at the end of the paper that his research had gone far enough to show promise for prescribed burning as a management tool (and this was 1958).

Harold Biswell developed prescribed fire techniques for California ponderosa pine forests by the late 1950s. Certainly more research was warranted but what he found was in agreement with earlier work done by Harold Weaver in ponderosa pine forests in eastern Oregon and Washington, USA (Weaver 1943). Had his recommendations been accepted by state and federal forest managers in the 1960s, California forests would be in much better shape today. At the very least, some UC Berkeley forestry faculty should have worked cooperatively with Biswell to further explore this topic.

Three of us (JA, JV, RW) were not only Harold's last Ph.D. students, but also his only Ph.D. students specializing in fire ecology. We were well acquainted with the antagonism expressed against him, primarily by state (California Division of Forestry), federal (Forest Service), and private (Keep California Green, an industrysponsored fire prevention association) foresters. There was little opposition to him burning in grasslands and shrublands, but when he began burning experiments in ponderosa pine forests, active and open criticism of him and his work exploded. He was referred to as "Harry the Torch," "Burn-Em-Up Biswell," and other derisive names, and not always behind his back. In early 1952, he led a group to Hoberg's to discuss the use of fire in forests and conduct a small prescribed burn. The few UC Berkeley School of Forestry faculty attending said little, but soon after, outside pressure mounted on Dean Frederick Baker to muzzle Harold (Biswell 1989; Miller 2020). Dean Baker wrote Biswell a letter asking him to discontinue any work at Hoberg's and confine his fire research to rangelands. Biswell gathered some allies from the University Agricultural Experiment Station, which administered all agricultural and natural resources research at the University, and soon Dean Baker was admonished for writing the letter and wrote a letter of apology to Harold. 


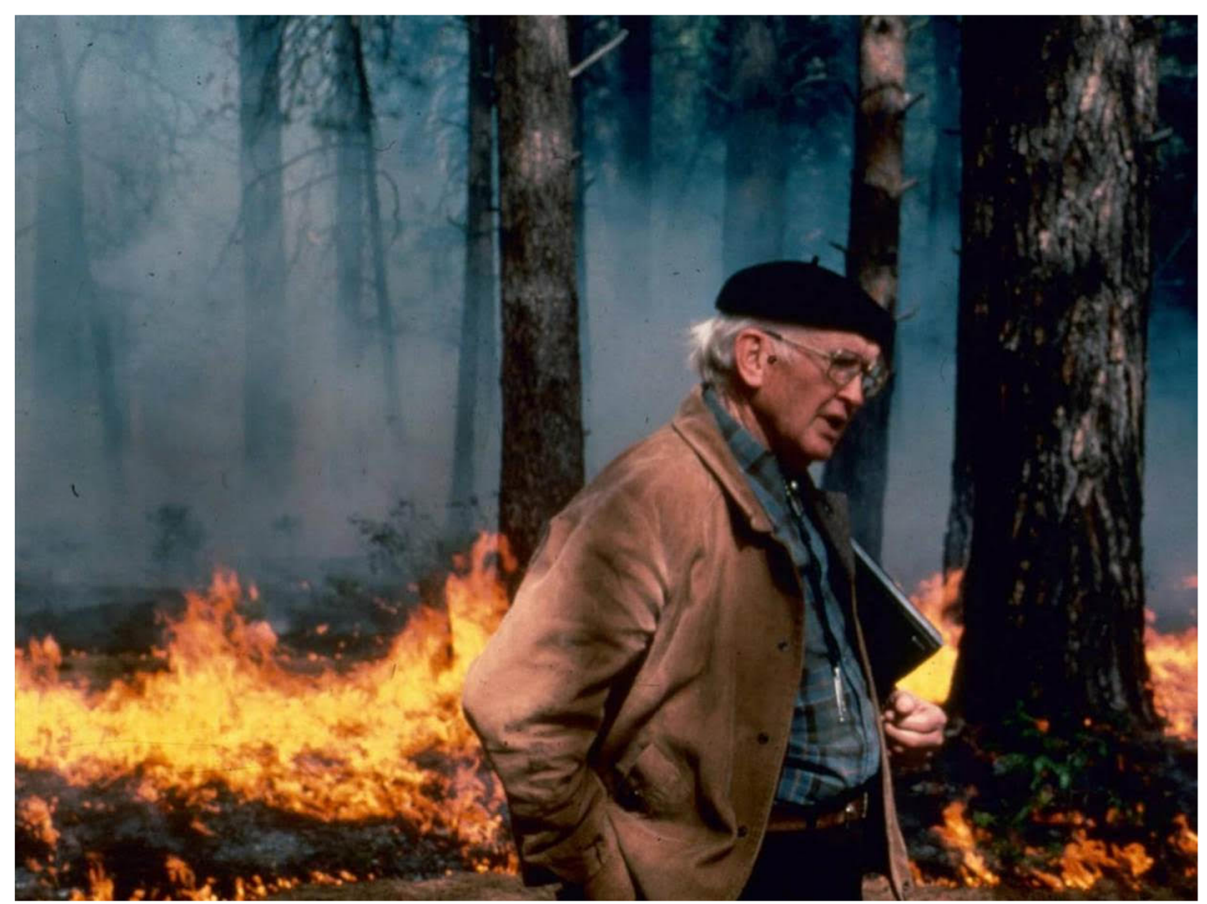

Fig. 1 Harold Biswell leading a discussion about prescribed fire during one of his field days in Yosemite National Park, California, USA, fall 1976. Photo credit: Mike Yost

Harold did have some supporters on the UC Berkeley faculty. Arnold Schultz, another member of the range faculty, conducted research with Harold and was co-author on many publications (Biswell and Schultz 1957; Schultz and Biswell 1959). Emanuel Fritz, who wrote a classic monograph on fire in the redwood (Sequoia sempervirens [D. Don] Endlicher) region, wrote to the director of Keep California Green in support of Harold, but he also cautioned Harold to publish in scientific journals and avoid interacting with the public. And perhaps the most significant supporter was A. Starker Leopold. Biswell's influence on Leopold encouraged him to expand a report that was written simply to deal with Rocky Mountain elk (Cervus canadensis nelsoni Erxleben, 1777) populations around Yellowstone National Park into a policy document (Leopold et al. 1963) that transformed national park policy on fire and led to adoption five years later of a National Park Service policy to use prescribed burns to restore historical conditions and to allow natural fires to burn under certain conditions. For the most part, the UC Berkeley School of Forestry faculty adopted a policy of benign neglect towards Harold, although they did vote to deny him access to the School's Blodgett Forest for any fire research. That policy also extended to his graduate students years later. He was allowed to burn at Whitaker's Forest, another School forest adjacent to Kings Canyon National Park, where active forest management for wood production was not emphasized (Kilgore and Biswell 1971).
When Dean Baker retired, Henry Vaux became Dean, and Vaux, while not enthusiastically supportive, encouraged Harold to work more with professional foresters. But silly arguments persisted on the faculty. One silviculture professor argued that fire could not be defined as a thinning tool, because although it reduced tree density, it could not precisely define spacing. And in 1968, the succeeding Dean of the School, John Zivnuska, wrote an article in the Journal of Forestry on the role of fire in watershed management, claiming it was directed to chaparral landscapes of southern California (Zivnuska 1968). But he then discussed the scheduling of prescribed burns in Biswell's Lake County pine forests, claiming that the 50 "good" burn days per year would be insufficient to support a broad program of prescribed burning. Dean Zivnuska presented a purely hypothetical example of the costs of a prescribed burn escape, claiming a cost of $\$ 6500$ to be charged against any prescribed fire, using two land-clearing fire escapes as examples. However, he did not develop a similar set of probabilities and costs of the reduction of damage from wildfires in areas where prescribed fires were used.

Beginning in the early 1950s and continuing until his mandatory retirement in 1975, Harold continued not only his research but a broad extension program of workshops, demonstration tours, and public lectures (Fig. 1). In 1973, he was awarded the Berkeley Citation, awarded for his contribution to the University of 
California that "go beyond the call of duty and whose achievements exceed the standards of excellence in their fields."

\section{Acknowledgements}

We thank the reviewer for helpful comments.

\section{Authors' contributions}

JV conceived the concept of this article. SS and JA wrote major sections, and JV and RW contributed to the writing. All authors read and approved the

final manuscript.

\section{Funding}

Funding from the University of California, Berkeley, contributed to the writing of this article.

\section{Availability of data and materials}

No datasets were used.

\section{Declarations}

Ethics approval and consent to participate

Not applicable.

\section{Consent for publication}

Not applicable.

\section{Competing interests}

The authors declare no competing interests.

\section{Author details}

'Department of Environmental Science, Policy, and Management, 130 Mulford Hall, University of California, Berkeley, California 94720, USA.

${ }^{2}$ National Park Service, Yosemite National Park, P.O. Box 700, El Portal, California 95318, USA. ${ }^{3}$ School of Environmental and Forest Sciences, University of Washington, 4000 15th Avenue, Seattle, Washington 98195, USA. ${ }^{4}$ Franke College of Forestry and Conservation, University of Montana, 32 Campus Drive, Missoula, Montana 59812, USA.

Received: 20 November 2020 Accepted: 4 February 2021

Published online: 22 April 2021

\section{References}

Biswell, H.H. 1958. Prescribed burning in Georgia and California compared. Journal of Range Management 11 (6): 293-297. https://journals.uair.arizona. edu/index.php/jrm/article/view/4884/4495. https://doi.org/10.2307/3894106.

Biswell, H.H. 1989. Prescribed burning in California wildlands vegetation management. Berkeley: University of California Press. https://doi.org/10.1525/ 9780520354067.

Biswell, H.H., and A.M. Schultz. 1957. Surface runoff and erosion as related to prescribed burning. Journal of Forestry 55 (5): 372-374.

Bruce, D. 1923. Light burning: report of the California Forestry Committee. Journal of Forestry 21 (2): 129-130.

Kilgore, B.M., and H.H. Biswell. 1971. Seedling germination following fire in a giant sequoia forest. California Agriculture 25 (2): 8-10.

Leopold, A.S., S.A. Cain, C.A. Cottam, I.N. Gabrielson, and T.L. Kimball. 1963. Wildlife management in the National Parks. American Forestry 69 (32-35): 6163.

Miller, R. 2020. Prescribed burns in California: a historical case study of the integration of scientific research and policy. Fire 3 (44). https://doi.org/10.33 90/fire3030044

Schultz, A.M., and H.H. Biswell. 1959. Effect of prescribed burning and other seedbed treatments on ponderosa pine seedling emergence. Journal of Forestry 57 (11): 816-817.
Weaver, H. 1943. Fire as an ecological and silvicultural factor in the ponderosapine region of the Pacific slope. Journal of Forestry 41 (1): 7-15.

Zivnuska, J.A. 1968. An economic view of the role of fire in watershed management. Journal of Forestry 66: 596-600.

\section{Publisher's Note}

Springer Nature remains neutral with regard to jurisdictional claims in published maps and institutional affiliations.

\section{Submit your manuscript to a SpringerOpen ${ }^{\circ}$ journal and benefit from:}

- Convenient online submission

- Rigorous peer review

- Open access: articles freely available online

- High visibility within the field

- Retaining the copyright to your article

Submit your next manuscript at $\boldsymbol{\nabla}$ springeropen.com 